\title{
Efficiency of Pseudomonas aureofaciens colonization in wheat rhizosphere under model condition
} Vlasova A.I., Minaeva O.M.

National Research Tomsk State University, Tomsk, Russia E-mail: ales1995.com@mail.ru

Key message. The survival of Pseudomonas aureofaciens in the wheat rhizosphere was studied. A significant increase in the number of pseudomonads and tetracycline resistant bacteria was shown when introduced into the model system of strains. Keywords: Pseudomonas aureofaciens, colonization, phytopathogen, rhizosphere

In modern agriculture, the use of bioformulations as an alternative to chemical pesticides is widespread. This makes it relevant to study the bacteria ability to survive in the rhizosphere and successfully compete with its natural inhabitants. Marking of strains, in particular resistance to increased doses of antibiotics, is used to evaluate the results of the colonization of bacterial strains into the agricultural plant rhizosphere under natural and laboratory conditions.

The aim of this research was to assess the introduction efficiency of Pseudomonas aureofaciens bacteria into the wheat rhizosphere in a model experiment.

The artificial terrestrial ecosystem was used in the experiment: sterile sand (substrate), wheat (Triticum aestivum L., cultivar Iren), bacteria $P$. aureofaciens, phytopathogen (Bipolaris sorokiniana). The parential and tetracycline resistant (0.4 g / 1$)$ bacterial strains were used in the experiment. Plants without bacterial inoculation with and without the phytopathogen were used as a control. The inoculation was carried out with liquid bacterial suspensions with a titer of $1 * 10^{6}$ cells/seed. The bacterial titer was analyzed by the Koch method on a general medium (total microbial number), media for genus Pseudomonas bacteria, and medium with tetracycline $(0.4 \mathrm{~g} / \mathrm{l})$ on the 14 th day after the experiment.

A statistically significant increase $(\mathrm{p}<0.05)$ in the total bacterial number when bacterial inoculation with and without phytopathogen was noted (more than 100 times in comparison with the control). Inoculation of the parental and tetracyclineresistant strains without a phytopathogen increased the number of the genus Pseudomonas bacteria in the substrate and on the roots of wheat over 20 times in relation to the control, and in antibiotic-resistant strains over 40 times, with a phytopathogen 75 times and 170 times, respectively. This indicates the colonization efficiency of the studied bacteria. In addition, the possibility of using tetracycline resistance as a genetic marker of $P$. aureofaciens bacteria in the study of their properties has been experimentally shown.

\section{Эффективность интродукции бактерий Pseudomonas aureofaciens в ризосфере пшеницы в модельных условиях} Власова А.И., Минаева О.М.

Национальный исследовательский Томский государственный университет, Томск, Россия

\begin{abstract}
Аннотация. Проведена оценка выживаемости Pseudomonas aureofaciens в ризосфере пшеницы. Показано значимое увеличение численности псевдомонад и бактерий, устойчивых к тетрациклину, при интродукции в модельную
\end{abstract} систему опытных штаммов.

Ключевые слова: Pseudomonas aureofaciens, интродукция, фитопатоген, ризосфера

В современном сельском хозяйстве широко распространено применение биопрепаратов как альтернативы химическим пестицидам, что делает актуальным изучение способности бактерий выживать в зоне ризосферы, успешно конкурируя с ее естественными обитателями. Для оценки успешности интродукции используются маркировки штаммов, в частности устойчивость к повышенным дозам антибиотиков, которая позволяет проследить судьбу используемых для бактеризации сельскохозяйственных растений бактерий в естественных и лабораторных условиях.

Цель работы: оценка эффективности интродукции бактерий Pseudomonas aureofaciens в ризосферу пшеницы в модельном эксперименте.

Для проведения эксперимента была создана наземная искусственная экосистема: стерильный песок (субстрат), пшеница (Triticum aestivum L., сорт Ирень), бактерии P. aureofaciens, фитопатоген (Bipolaris sorokiniana). B эксперименте использовали бактерии родоначального и резистентного к тетрациклину $(0,4$ г/л) штаммов. Контроль растения без инокуляции бактериями с фитопатогеном и без. Интродукцию проводили жидкими бактериальными суспензиями из расчета $1 * 10^{6}$ клеток/семя. Численности учитывали методом Коха на общеупотребительной среде (общее микробное число), средах для бактерий рода Pseudomonas и среде с тетрациклином (0,4 г/л) на 14 сутки после постановки эксперимента.

Отмечено статистически значимое увеличение общей численности бактерий в вариантах с бактериальной интродукцией как с фитопатогенном, так и без него (более чем в 100 раз по сравнению с контролем). При интродукции родоначального и резистентного к тетрациклину штаммов в вариантах без фитопатогена в субстрате и на корнях пшеницы увеличивалась численность бактерий рода Pseudomonas свыше 20 раз по отношению к контролю, а резистентных к антибиотику - свыше 40, в вариантах с фитопатогеном - 75 раз и 170 раз соответственно, что свидетельствует об успешности интродукции изучаемых бактерий. Кроме того, экспериментально показана возможность применения резистентности к тетрациклину в качестве генетического маркера бактерий $P$. aureofaciens при изучении их свойств. 